Ann. Biol. anim. Bioch. Biophys., I976, 16 (4), 529-536.

\title{
PREOVULATORY LH RELEASE AND OVULATION IN DRY AND IN LACTATING EWES AFTER PROGESTAGEN AND PMSG TREATMENT DURING THE SEASONAL ANOESTRUM
}

\author{
Y. COGNIE and J. PELlETIER \\ with technical assistance of A. CARATY \\ Station de Physiologie de la Reproduction, \\ Centre de Recherches de Tours, I. N. R. A., \\ Nouzilly, 37380 Monnaie
}

Onset of oestrus and the time of ovulation was compared in dry ewes and in lactating ewes treated with progestagen (FGA) impregnated vaginal sponges followed by a PMSG injection during the non sexual season. In other ewes treated in the same way LH release and the age of corpora lutea were studied.

The onset of oestrus was earlier in dry ewes than in lactating ewes $(33.9 \pm 0.98 \mathrm{hr} v s 36.7$ $\pm 0.45 \mathrm{hr} ; \mathrm{P}<0.05$ ) but the interval between oestrus and the first ovulations was shorter in the latter than in the former $(24.5 \pm \mathbf{I}$.I hr vs $27.5 \pm 0.8 \mathrm{hr} ; \mathrm{P}<0.05)$, thus in both groups the first ovulations occurred $62.0 \pm \mathrm{I} . \mathrm{O} \mathrm{hr}$ after sponge removal.

However, by comparing the number of ovulations at 72 and roo hr after sponge removal, it was apparent that late ovulations occurred in both groups, with a significant difference $(2.1 \pm 0.3$ vs $3.4 \pm 0.6$ corpora lutea; $\mathrm{P}<0.05$ ) in the lactating females only. This could explain why the mean age of corpora lutea, estimated Ioo $\mathrm{hr}$ after sponges removal, differed between lactating ewes and dry ewes $(25.3 \pm 2.3 \mathrm{hr} v s 35.0 \pm 2.0 \mathrm{hr} ; \mathrm{P}<0.01)$.

Although $\mathrm{LH}$ release was found $25 \mathrm{p}$. Ioo less in lactating than in dry ewes, it seems probable that this cannot explain all the differences between the two groups at the ovarian level.

\section{INTRODUCTION}

Precise knowledge of the timing of the onset of oestrus and of ovulation following the end of a vaginal progestagen treatment (CogNIE, MARIANA and THIMONIER, 1970) has allowed a high fertility rate in dry ewes after artificial insemination whatever the season (CoIAS et al., I97I). 
However, in breeds having a short sexual season and in ewes which have had several litters a low fertility was observed when lactating animals were inseminated before $5^{\circ}$ days after parturition during the seasonal anoestrum (THIMONIER et al., I968, Cognie, Cornu and Mauléon, r974).

Previous experiments have shown that almost all lactating ewes ovulate following progestagen, PMSG treatment (PELIETIER and THIMONIER, I973, I975). We have now examined in greater details in two experiments :

I. The onset of oestrus and the timing of ovulation in lactating and in dry ewes after vaginal progestagen treatment during the non-sexual season.

2. The $L_{L} H$ release and the age of corpora lutea in lactating and dry ewes roo hours after the end of vaginal progestagen treatment. Since it has been observed that such a vaginal progestagen treatment can depress the hypothalamo-hypophyseal activity in lactating females (PELLETIER and THIMONIER, I972), we have attempted to reduce this effect by decreasing the duration of progestagen treatment in one group of lactating animals.

\section{MATERIAL AND METHODS}

The protocol of the two experiments performed during the seasonal anoestrum (march to may) is given in table $\mathbf{I}$.

TABLE, I

Experimental protocols in experiments $I$ and $I I$

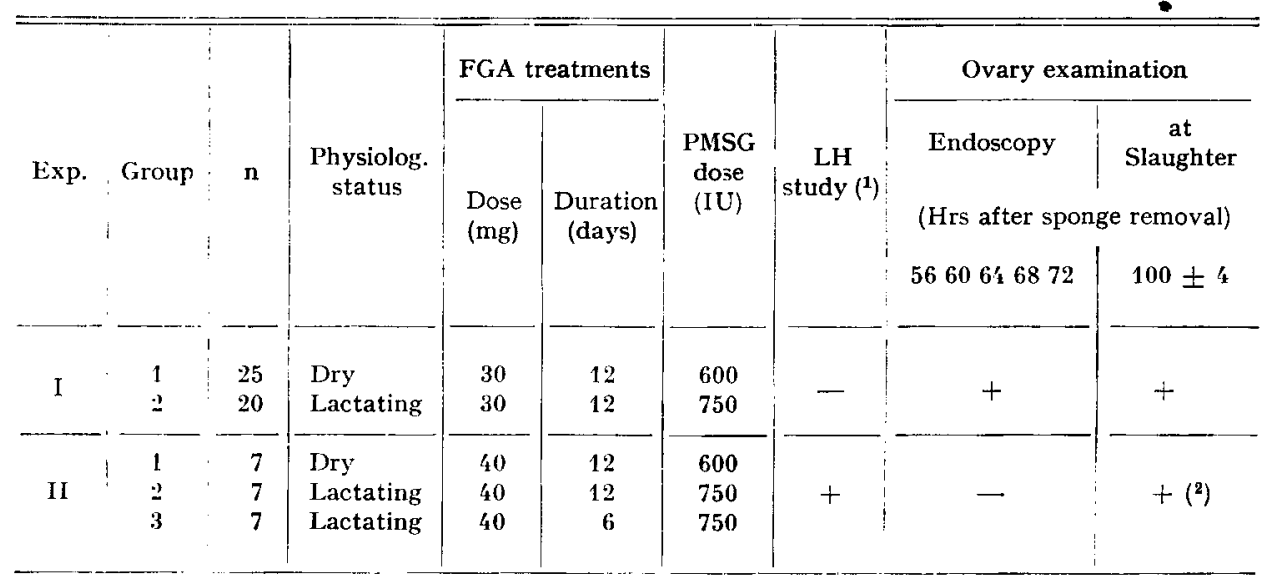

(1) Blood samples were collected into heparinised tubes by venepuncture every two hours for $26 \mathrm{hr}^{\mathrm{S}}$ after onset of oestrus.

$\left({ }^{2}\right)$ Histological study of ovaries : diameter measurements of granulosa cells.

\section{Animals and treatments}

Ile-de-France ewes, two to ten years old, were used. Lactating females were kept with one lamb until the end of experiment. Dry ewes acted as controls.

Vaginal sponges impregnated with fluorogestone acetate (FGA, Searle) were inserted for 
twelve days in experiment $I$ and six or twelve days in experiment II. At the time of sponge removal (9 AM), PMSG (Organon, OSS) was injected intramuscularly. The doses of PMSG, 600 i.u. for dry ewes and $75^{\circ} \mathrm{i} . \mathrm{u}$. for lactating ewes were chosen in order to induce oestrus and ovulation in all the females (THImonier and CoGNie, 1971). When the PMSG was given the lactating ewes were $42 \pm 4$ days (exp. I) and $39 \pm 5$ days (exp. II) post-partum.

Females were exposed to aproned rams for one hour every four hours from the 24 hours after the PMSG treatment. They were considered to be in oestrus if, when standing, they were mounted by the ram (MAULÉon and DAUzIER, 1965). Such ewes were transfered to another pen without a ram to prevent modification of the timing of ovulation (PARsons and HUNTER, 1967; L.INDSAY et al., 1975).

\section{Plasma L.H assay}

Plasma LH was estimated (exp. II) by radioimmunoassay (Pelletien et al., I968). Results are expressed in C.N.R.S. LH-M 3 ( $\times$ I. 8 NIH-LH-SI). The total LH release at oestrus was calculated from the area bounded by the curve of the LH levels and a baseline (mean plasma LH level before preovulatory surge) assumed to be constant. It was expressed in $\mathrm{ng} / \mathrm{ml}$ per one hour as if all the release had occurred in one hour at constant rate.

\section{Control of ovulation}

Ovulation time was determined in experiment I by coelioscopic observation of the ovaries (Thimonier and MAULEON, 1969) 56 hours after sponge removal and then every four hours until the appearance of the first ovulation points in each female. Gas anaesthesia (fluothane) was only used for about five minutes in order not to modify the ovulation time.

The number of ovulations was estimated by counting corpora lutea at endoscopy (exp. I), or at slaughter Ioo \pm 4 hrs after sponge removal (exp. I and II).

Age of the induced corpora lutea was estimated in ewes of experiment II by measurement on each corpora lutea, of diameters in Ioo luteal cells from granulosa origin. It has been shown that those diameters were correlated with the age of corpora lutea (CoRTEEL and MAULEON, I973).

\section{RESULTS \\ I. - Onset of oestrus (experiments I and II)}

Ninety p. Ioo of all lactating or dry females came into oestrus 28 to 44 hours after sponge removal. The interval between sponge removal and the onset of oestrus was shorter in dry than in lactating ewes $(33.9 \pm 0.98 \mathrm{hr} v s 36.7 \pm 0.45 \mathrm{hr}$; $\mathrm{P}<0.05)$ although the former received a lower dose of PMSG. In lactating females the interval was not affected by the length of progestagen treatment.

Cumulative frequency of onset of oestrus is shown in figure $r a$. Four lactating females did not come into oestrus but two of them ovulated and were included in the following results.

\section{II. - Preovulatory $L H$ release (experiment II)}

A peak value of plasma $\mathrm{LH}$ level occurred 4.0 to $6.6 \mathrm{hrs}$ after the beginning of oestrus (table 2) in dry ewes and lactating ewes respectively. The duration of the increased $\mathrm{LH}$ release and the value of the peak were higher in dry than in lactating ewes. Although each of those differences were not significant, the total $\mathrm{LH}$ release which integrates both parameters, was significantly higher in dry than in lactating ewes $(P<0.05)$. Again the length of progestagen treatment did not influence the total $\mathrm{L} H$ release. 
TABLE 2

Induced preovulatory $L H$ release in dry ewes and in lactating ewes in experiment II

\begin{tabular}{|c|c|c|c|c|c|c|}
\hline Group. & Phys. status & $\mathrm{n}$ & $\begin{array}{c}\text { Oestrus-LH } \\
\text { peali interval } \\
\text { (hrs) }\end{array}$ & $\begin{array}{c}\text { LH release } \\
\text { duration } \\
\text { (hrs) }\end{array}$ & $\begin{array}{l}\text { LH peak level } \\
(\mathrm{ng} / \mathrm{ml})\end{array}$ & $\begin{array}{c}\text { Total } \\
\text { LH release } \\
(\mathrm{ng} / \mathrm{ml} /(1 \mathrm{hr})(\mathbf{1})\end{array}$ \\
\hline 1 & Dry & $\bar{i}$ & $4.0 \pm 1.4$ & $11.7 \pm 0.7$ & $106.7 \pm 11.2$ & $453 \pm 45.5$ \\
\hline 2 & $\begin{array}{l}\text { Lactating } \\
\text { (FGA } 12 \text { days) }\end{array}$ & 7 & $6.6 \pm 1.8$ & $11.1 \pm 0.7$ & $82.5 \pm 10.5$ & $346 \pm 42.3$ \\
\hline 3 & $\begin{array}{l}\text { Lactating } \\
\text { (FGA } 6 \text { days) }\end{array}$ & 7 & $4.3 \pm 1.1$ & $10.0 \pm 0.6$ & $87.6 \pm \quad 9.3$ & $328 \pm 32.2$ \\
\hline
\end{tabular}
rate.

(1) Computed from the area under LH curve as if all the release had occurred in one hour at constant

\section{III. - Ovulation time (experiment I)}

The first ovulation points occurred $62.0 \pm$ I.o hours after sponge removal in both groups. The interval between the beginning of oestrus and the first occurrence of ovulations was lower in lactating than in dry ewes (24.5 \pm I.I hr vs $27.5 \pm 0.8 \mathrm{hr}$; $\mathrm{P}<0.05)$.

The cumulative frequency of intervals from sponge removal to first ovulations is given in figure $\mathrm{I} b$.

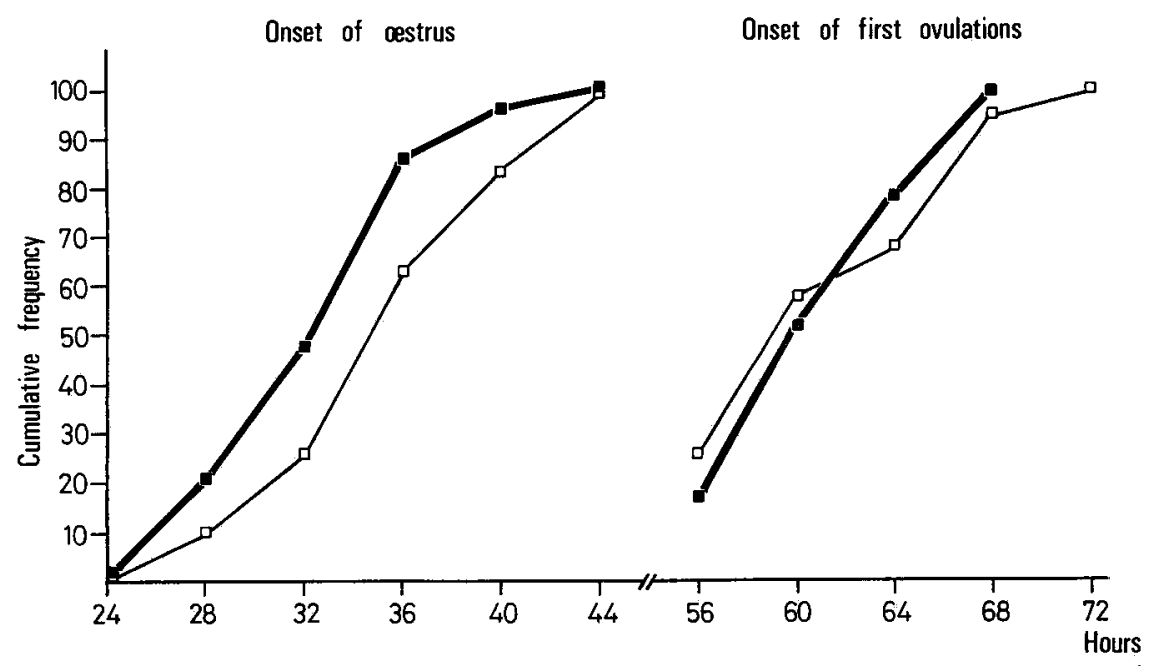

Time after sponge removal

FrG. I, - Cumulative frequencies for intervals between sponge removal and a) onset of oestrus; b) occurrence of first ovulations in dry and in lactating ewes

( $\square$, dry ewes ; $\square \longrightarrow \square$ lactating ewes) 
Number of ovulations (experiment I and II).

The mean number of ovulations observed by endoscopy 56 to $72 \mathrm{hr}$ after sponge removal (exp. I) was $2.4 \pm 0.3$ in dry ewes and $2.1 \pm 0.3$ in lactating ewes. It was $3 . I \pm 0.6$ and $3.4 \pm 0.6$ respectively, however, when ovaries were examined following slaughter, Ioo hours after sponge removal (exp. I and II).

Analysis of variance showed that the difference in the number of ovulations at the two periods of observation was significant $(\mathrm{P}<0.05)$ only in lactating females (table 3) and thus, that late ovulations occurred mainly in this case.

TABLE 3

Number of ovulations in relation to the delay after the sponge removal

\begin{tabular}{|c|c|c|c|c|c|c|c|c|c|}
\hline \multirow{2}{*}{ Phys. Status } & \multirow{2}{*}{$n$} & \multirow{2}{*}{$\begin{array}{c}\text { Observat. } \\
\text { time (hrs) } \\
\text { (1) }\end{array}$} & \multicolumn{6}{|c|}{ Females $(\%)$ with } & \multirow{2}{*}{$\begin{array}{l}\text { Mean Number } \\
\text { of C.L./P }\end{array}$} \\
\hline & & & 1 & 2 & 3 & 4 & 5 & $>5 \mathrm{CL}$ & \\
\hline Dry ewes & $\geq 5$ & $\begin{array}{r}56-72 \\
100 \pm 4\end{array}$ & $\begin{array}{l}30 \\
26\end{array}$ & $\begin{array}{l}35 \\
26\end{array}$ & $\begin{array}{l}17 \\
26\end{array}$ & $\begin{array}{l}9 \\
4\end{array}$ & $\begin{array}{l}4 \\
9\end{array}$ & $\begin{array}{l}4 \\
9\end{array}$ & $\left.\begin{array}{l}2.4 \pm 0.3 \\
3.1 \pm 0.3\end{array}\right\} \mathrm{NS}$ \\
\hline $\begin{array}{l}\text { Lactating } \\
\text { ewes }\end{array}$ & 20 & $\begin{array}{r}56-72 \\
100 \pm 4\end{array}$ & $\begin{array}{l}47 \\
21\end{array}$ & $\begin{array}{l}16 \\
21\end{array}$ & $\begin{array}{l}21 \\
21\end{array}$ & $\begin{array}{l}16 \\
16\end{array}$ & $\begin{array}{l}0 \\
6\end{array}$ & $\begin{array}{r}0 \\
16\end{array}$ & $\left.\begin{array}{l}2.1 \pm 0.3 \\
3.4 \pm 0.6\end{array}\right\} P<0.05$ \\
\hline
\end{tabular}

(1) Observation time after the sponge removal.

Age of corpora lutea (experiment II).

It is clear from figure 2 that there was a difference between dry ewes and lactating ewes in the distribution of the ages of corpora lutea in ewes slaughtered roo $\mathrm{hr}$ after sponge removal. The mean age of corpora lutea in dry ewes $(35.0 \pm 2.0 \mathrm{hr}$ )
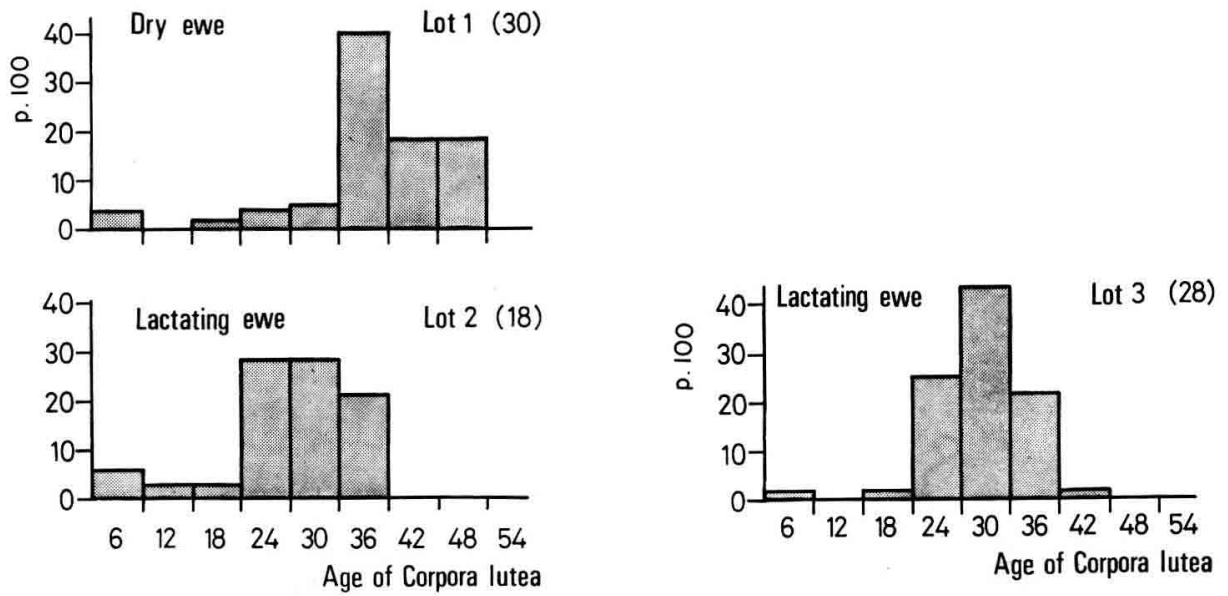

Fig. 2. - Estimation of corpora lutea ages (from the diameters of the granulosa cells) $100 \pm 4$ hrs after the end of progestagen treatment in dry exes (lot I) and in 12 days (lot 2) or 6 days (lot 3) FGA treated lactating eves. ( ), number of corpora lutea studied in each group.

Annales de Biologie animale. - r976. 
was significantly greater than in lactating ewes treated with FGA for 6 days $(28.9 \pm \mathrm{I} .3 \mathrm{hr} ; \mathrm{P}<0.05)$ or I 2 days $(25.3 \pm 2.3 \mathrm{hr} ; \mathrm{P}<0.01)$. There was not significant difference between the two groups of lactating females.

\section{DISCUSSION}

The PMSG injection required to induce oestrus in all the females during the non breeding season, decreases the time interval between the end of progestagen treatment and the onset of oestrus (CogniE, Mariana and Thimonier, I970). However, the interval between removal of the progestagen sponge and onset of oestrus is shorter in dry than in lactating ewes, although the former received a smaller dose than the latter. Similar result has been shown previously (PELLETIER and THIMONIER, I973).

On the other hand, the first ovulations occurred earlier after onset of oestrus in lactating than in dry ewes. The higher dose of PMSG given to lactating ewes than to dry ewes may explain the shorter interval observed in the former. Indeed CoGNIE, MARIANA and THIMONIER (I970) have shown that this interval was shorter in females injected with PMSG than in untreated ewes.

The $\mathrm{LH}$ release started about one to three hours after the onset of oestrus in both groups of females in experiment II. This interval is shorter than that usually observed in dry ewes of the same breed synchronized in sexual season (LAND et al., 1973) or in lactating or dried ewes of Finn $\times$ Dorset breed synchronized in sexual season but without PMSG treatment (ShEVAH et al., 1974).

The interval between LH peak and ovulation would be constant ( $25 \mathrm{hrs})$ in normal or progestagen treated cyclic ewe according to Cumming et al. (1971).

The results presented here indicate that ovulations in superovulated females are not synchronous, particularly in lactating females where a significant greater number of ovulations was recorded roo hr after sponge removal than at $72 \mathrm{hr}$. Thus, in spite of the fact that the first ovulations occurred at the same interval after sponge removal, $62.0 \mathrm{hr}$ in both groups of exp. I, the mean age of corpora lutea measured at slaughter of the ewes in exp. II, was less in the lactating females than in the dry females.

By calculating the time of ovulation from the age of corpora lutea data in exp. II, it is apparent that the time of first ovulations of dry ewes occurred at approximately the same time in both experiments. However, in the lactating females of exp. II, it can be seen (fig. 2) that the time of first ovulations occurred later than in the lactating ewes of exp. I.

In addition to more late ovulations in lactating ewes, a lower growth rate of corpora lutea is suggested by the smaller size of 7 day old corpora lutea in lactating ewes than in dry ewes (COGNIE, unpublished results).

The $\mathrm{L}_{\mathrm{H}}$ release is quantitatively less in lactating ewes than in dry ewes. This agrees with the results of PELLETIER and ThIMONIER (I973) and LEWIS, BoLT and INSKEEP (1974) and is to be related to a lower pituitary response to LRF in lactating ewes than in dry ewes during the non sexual season (PELLETIER, I974).

However, a deficiency in the preovulatory release of gonadotropins is not the 
only factor responsible for all the differences recorded between lactating and dry ewes at the ovarian level. The staggering of ovulations and the low growth rate of corpora lutea could indicate a greater latency of response of ovarian origin in lactating ewes. Further low plasma oestradiol and progesterone levels and poor egg recovery and fertilization rates have been recorded in lactating females (COGNIE; HERNANDEZ-BARRETO and SAUMANDE, I975).

Finally, if it is difficult to establish the origin of all the above mentionned differences, it appears that in addition to $\mathrm{LH}$ release, the follicular maturation, the development of eggs and corpora lutea may be of lower quality in lactating than in dry ewes synchronized during the non breeding season.

Rę̧u pour publication en octobre 1975.

\title{
RÉSUMÉ
}

\author{
DÉCHARGE PRÉOVULATOIRE DE LH ET OVULATION \\ CHEZ LA BREBIS SÈCHE ET CHEZ LA BREBIS ALIAITANTE \\ APRÈS TRAITEMENT PAR UN PROGESTAGÈNE E'T PMSG \\ DURANT I,A SAISON D'ANCESTRUS SAISONNIER
}

Le début de l'œstrus et le moment d'ovulation après traitement progestagène (éponge vaginale imprégnée de FGA) et injection de PMSG ont été comparés chez des brebis sèches et des brebis allaitantes pendant la période d'anœstrus saisonnier. Chez des animaux comparables, la décharge de LH dans le sang et l'âge des corps jaunes ont également été étudiés.

Le début de l'œestrus est plus précoce après retrait de l'éponge vaginale et injection de PMSG chez les brebis sèches que chez les brebis allaitantes $\left(33,9 \pm 0,98 \mathrm{~h} v \mathrm{~s}_{36,7} \pm 0,54 \mathrm{~h}\right.$; $\mathrm{P}<0.05)$ mais l'intervalle entre l'cestrus et les premières ovulations est plus court chez les secondes que chez les premières $(24,5 \pm \mathrm{I}, 05 \mathrm{~h} v s 27,5 \pm 0,8 \mathrm{~h} ; \mathrm{P}<0,05)$. Il en résulte que dans les deux groupes le délai entre le retrait de l'éponge vaginale et les premières ovulations est identique $(62,0 \pm 1,00 \mathrm{~h})$.

Cependant, l'âge moyen des corps jaunes diffère entre les brebis sèches et les brebis allaitantes $(25,3 \pm 2,3 \mathrm{~h}$ vs $35,0 \pm 2,0 \mathrm{~h} ; \mathrm{P}<0,0 \mathrm{I}) \mathrm{du}$ fait d'ovulations tardives plus fréquentes chez les brebis allaitantes $(2, \mathrm{I} \pm 0,3$ corps jaune $v s 3,4 \pm 0,6$ respectivement $72 \mathrm{~h}$ et Ioo $\mathrm{h}$ après l'arrêt du traitement progestagène; $\mathbf{P}<0,05)$.

Bien que la décharge préovulatoire de $\mathrm{LH}$ soit de $25 \mathrm{p}$. Ioo inférieure chez les brebis allaitantes que chez les brebis sèches, elle ne semble pouvoir expliquer toutes les différences enregistrées au niveau ovarien entre les deux groupes.

\section{REFERENCES}

Cognie Y., Mariana J. C., Thimonier J., 1970. Étude du moment d'ovulation chez la Brebis normale ou traitée par un progestagène associé ou non à une injection de PMSG. Ann. Biol. anim. Bioch. Biophys., 10, 15-24.

Cognie Y., Cornu C., Mauléon P., r974. The influence of lactation on fertility of ewes treated during post-partum oestrus with vaginal sponges impregnated with fluorogestone acetate (chronogest). Intern. Symp. Physio-Pathology of Reproduction and artificial insemination, Thessaloniki, I7-I9 May I974 (in press).

Cognie Y., Hernandez-Barreto M., Saumande J., r975. Low fertility in nursing ewes during the non breeding season. Ann. Biol. anim. Bioch. Biophys., 15, 329-343.

Colas G., Brice G., Courot M., Cottier M., i97I. L'insémination artificielle dans les plans d'intensification de la production ovine : état actuel et perspectives. Bull. techn. Inf. Ingrs servs. agric., 257, I 47 -I 52 . 
Corteel M., MaUlÉon P., I973. Aspects histologiques, histochimiques et ultrastructuraux de la formation et de l'involution du corps jaune. I-32, in R. Denamur, A. Netter. Le corps jaune, Ed. Masson et Cie, Paris.

Cumming I. A., Brown J. M., Blockey M. A. de B., Winfield G. G., Baxter R., Goding J. R., 1971. Constancy of interval between LH release and ovulation in the ewe. J. Reprod. Fert., 24, I 34-I 35 .

Land R. B., Pelletier J., Thimonier J., Mauléon P., i973. A quantitative study of genetic differences in the incidence of oestrus, ovulation and plasma luteinizing hormone concentration in the sheep. J. Endocr., 58, 305-3I7.

Lewis P. E., Bolt D. J., Inskeep E. K., I974. Luteinizing hormone release and ovulation in anoestrous ewes. J. anim. Sci., 38, II97-I203.

Lindsay D. R., Cognie Y., Pelletier J., Signoret J. P., I975. The influence of the presence of rams on the timing of ovulation and discharge of $\mathrm{LH}$ in ewes. Physiol. Behav. (In press).

Mauléon P., Dauzier L., I965. Variations de durée de l'anoestrus de lactation chez les brebis de race Ile-de-France. Ann. Biol. anim. Bioch. Biophys., 5, I3r-I43.

Parsons S. D., Hunter G. L., I967. Effect of the ram on duration of oestrus in the ewe. J. Reprod. Fert., 14, 6r-70.

Pelletier J., Kann G., Dolais J., Rosselin G., 1968. Dosage radioimmunologique de l'hormone luteinisante plasmatique chez le Mouton. Mise au point de la technique de dosage. C. R. Acad. Sc. Paris, Ser. D., 266, 2291-2294.

Pelletier J., Thimonier J., 1972. Influence of fluorogestone acetate (FGA) on hypothalamo-hypophysial activity in anoestrus dry and lactating ewes. J. Reprod. Fert., 31, 496-497.

Pelletier J., Thimonier J., 1973. Comparison of the induced preovulatory LH discharge in lactating and dry sheep during seasonal anoestrus. J. Reprod. Fert., 33, 310-313.

Pelletier. J., 1974. Influence de la lactation sur la décharge préovulatoire de LH induite par l'injection de LRF synthétique chez la Brebis durant la période d'anœstrus saisonnier. $C . R$. $A c a d$. Sc., Paris, Ser. D., 279, I79-182.

Pelletier J., Thimonier J., 1975. Interactions between ovarian steroids or progestagens and LH release. Ann. Biol. anim. Bioch. Biophys., 15, I3I-146.

SheVah Y., Black W. J. M., CarR W. R., LAND R. B., I974. The effect of lactation on the resumption of reproductive activity and the preovulatory release of $\mathrm{LH}$ in Finn $\times$ Dorset. J. Reprod. Fert., 38, 369-378.

Thimonier J., Cognie Y., r97r. Accélération des mises bas et conduite d'élevage chez les ovins. Bull. Tech. Inform. Minist. A gric., 247, 187 -196.

Thimonier J., Mauléon P., I969. Variations saisonnières du comportement d'œestrus et des activités ovarienne et hypophysaire chez les ovins. Ann. Biol. anim. Bioch. Biophys., 9, 233-250.

Thimonier J., Mauléon P., Cognie Y., Ortavant R., ig68. Déclenciement de l'œstrus et obtention de la gestation pendant l'ancestrus post-partum chez la Brebis à l'aide d'éponges vaginales imprégnées d'acétate de fluorogestone. Ann. Zootech., 17, 257-273. 